\title{
Tarih İçinde Yunanistan'da Türk Dili: Hun-Avar-Bulgar Dönemi
}

\section{The Turkic Language in Greece Throughout History: The Hunic- Avaric-Bulghar Period}

\author{
Gökçe Yükselen Peler ${ }^{1 \odot}$
}

'Dr. Öğr. Üyesi, Erciyes Üniversitesi, Edebiyat Fakültesi, Çağdaş Türk Lehçeleri ve Edebiyatları Bölümü, Kayseri, Türkiye

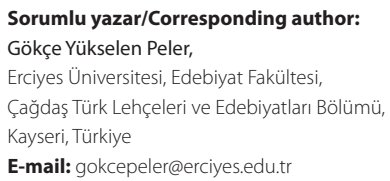

Geliş tarihi/Date of receipt: 03.09 .2018 Kabul tarihi/Date of acceptance: 11.10.2018

\section{Atıf/Citation:}

Peler, G. Y. (2018). Tarih içinde Yunanistan'da Türk dili: Hun-Avar-Bulgar dönemi. TUDED 58(2), 429-448

https://doi.org/10.26650/TUDED2018-0004

\section{ÖZET}

Günümüzde Oğuz Türkçesi değişkelerinin konuşulduğu Yunanistan'da geçmişte Türkçenin farklı lehçe gruplarına ait değişkelerin konuşulduğu bilinmektedir. Bugünkü manzaranın ortaya çıkması büyük oranda Osmanlı dönemi ile ilgilidir. Ancak Osmanlı dönemi öncesinde Hunlar, Avarlar, Ogurlar, Bulgarlar, Peçenekler, Kumanlar, Uzlar gibi Türk halkları Yunanistan'a gelip yerleşmişlerdir. Bu halklardan Hunlar, Avarlar, Ogurlar ve Bulgarlar, geriye kalan Türk halklarından farklı olarak Bulgar Türkçesi konuşmakta idi ve çeşitli dönemlerde Yunanistan'ı istila edip oraya yerleşmişlerdir. Bu halkların Yunanistan'a geliş tarzlarına göre dillerinin toplumluk etkileri de çeşitlilik göstermiştir. Bu dönemde Türkçe Yunanistan'da kimi zaman bir göçmen veya yerleşimci dili olurken kimi zaman ordu dili olmuştur. Kimi zaman sadece cemiyet dili olarak kalırken kimi zaman da yönetim dili hâline gelmiş, hatta Latince ve Yunanca gibi köklü dillere rağmen uluslararası iletişim ve diplomasi dili hâline gelmiştir. Elbette toplumluk etkinliği konuşurlarının toplum içerisindeki etkinliği ile doğrudan ilişkili idi. Bundan dolayı Türkçe; Hun, Avar, Ogur ve Bulgar dönemlerinde Yunanistan'da birbirinden çok farklı ama kimi zaman da birbiri ile ilişkili bir şekilde toplumluk yer edinmiştir. Bu çalışmanın amacı, elde var olan kısıtlı tarihî kayıtlardan hareketle Bulgar Türkçesi konuşan bu dört kavmin Yunanistan'ı istilaları esnasında ülkede Türkçenin edindiği toplumluk etki ve etkinliğini tespit etmektir.

Anahtar Kelimeler: Bulgar Türkçesi, Yunanistan, Yönetim Dili, Cemiyet Dili, Ordu Dili

\section{ABSTRACT}

Contemporary Greece is an environment where varieties of Oghuz Turkic are spoken. However, it is known that different Turkic varieties, other than contemporary ones, were spoken in the country in the past. The emergence of the present scenery is a substantial outcome of the Ottoman period. Nevertheless, Turkic groups like the Huns, Avars, Oghurs, Bulghars, Pechenegs, Cumans, and the Oghuz had arrived in Greece and settled there. The former four spoke Bulghar Turkic (Proto-Bulgarian), as distinct from the rest, and had invaded and settled in Greece at different periods. The social influence of their languages varied in accordance with the manner they arrived in Greece. In this period, Turkic sometimes had served as an immigrant or a settler language, whereas sometimes it was used as the language of soldiery. Occasionally, it was solely used as a community language, whereas sometimes it was used as the language of the administration. As a matter of fact, it even had 
been used as a lingua franca, despite deep-seated languages like Latin and Greek. Naturally, the social strength of the language was directly related to the social status of its speakers. Therefore, Turkic had gained various social statuses in Greece during the Hunnic, Avaric, Oghur, and Bulghar periods. However, these statuses were sometimes influenced by each other. This work aims to establish the social influence and strength of Turkic in Greece during the invasion of these four Bulghar Turkic-speaking groups with reference to limited historical records on hand.

Keywords: Bulghar Turkic, Greece, Language of Administration, Community Language, Army Language

\section{EXTENDED ABSTRACT}

There is no doubt that Turkic groups like the Huns, Avars, Oghurs, and Bulghars, who surged into the Balkans between the $4^{\text {th }}$ and $10^{\text {th }}$ centuries initially carrying out raids but then settling into the Balkans in general and Greece in particular, had brought their language with them. The languages of all four groups were varieties belonging to Turkic languages, which are universally called (Old) Bulghar Turkic, Hun-Bulghar Turkic, or Old Western Turkic. Therefore, they either provided a basis for or consolidated with each other. In this period, Turkic entered Greece in various forms. It was sometimes used as the language of the invader, sometimes as the language of refugees or settlers, and sometimes it merely remained as a community language, whereas sometimes it had become the language of the administration.

In parallel with the military and political powers of the Hunnic state, Turkic became the language of international communication and diplomacy, surpassing Latin and Greek during the Hunnic period. Historical records provide evidence that the Turkic language survived in Greece as a language of refugees and soldiery after the collapse and disintegration of the Hunnic state. Despite the small amount of data on hand when compared to the Hunnic period, it could be assumed that the Turkic language had a firmer status during the Avaric period, as the Avar dominance in Greece had lasted longer and was more entrenched than that of the Huns. The Peloponnese, in particular, had remained in the hands of the Avars for a very long period. Historical records provide information that the institutions of the Byzantine civilization and culture were erased from the surface of the peninsula, and "barbarism" ruled for more than two centuries. The Avaric names of places among the Greek and Balkanic toponymy could be considered as evidence that a more influential Turkic element existed during the Avar period than that of the Hunnic period. Clearly, a more influential population meant a more influential language. Most probably, the Avars had encountered Hunnic residues in Greece, who had spoken a language similar to theirs, and absorbed them, strengthening their linguistic basis. Additionally, some Oghur groups arrived and settled in Greece shortly before the Avars and after the collapse of the Hunnic state. On the other hand a number of Oghur and Bulghar groups entered and settled in Greece together with the Avars. All of these factors must had consolidated Turkic as a community language, which was already serving as the language of the administration during the Avar period. 
It is a widespread view that the Avars were absorbed by the Slavonic groups. However, there is evidence that this did not happen, at least in some regions. There is a great possibility that in some regions of Greece, the Avars were incorporated into the Bulghar state, which domineered the whole of the Balkans after them, without losing their language. Layers of Turkic peoples, who had poured into the Balkans in general and Greece in particular, entrenched and enrooted the Turkic language in the region. However, the Bulghars inherited the mission of dominating and ruling all of the Slavonic peoples from the Avars, and this mission eventually paved the way to the disappearance of a Turkic community, which evolved over five to six centuries. The Turkic language disappeared together, perhaps before the people, as they were outnumbered by the Slavs and absorbed by them. The Turkic groups of the Hunnic-Avaric-Bulghar period in Greece were initially Slavicized and later Grecified to a great extent after Byzantine rule was reestablished in Greece. 


\section{Gíriş}

Günümüzde Yunanistan'da Türk dili, yedi grup insan tarafından kullanılmaktadır. Bunlar; Osmanlı fetihleri neticesinde gelip bölgeye yerleşen Gümülcine ve İskeçe bölgelerinde yaşayan Batı Trakyalı Müslüman Türkler, yine Batı Trakya'da Balkan Kolu denilen bölgede yaşayan Müslüman Pomak Türkleri, Batı Trakya'da yaşayan Müslüman Romanlar, On İki Adalarda yaşayan Müslüman Türkler, genellikle Dedeağaç (Evros) ilinde yaşayan ve Gagavuz denilen Hristiyan Türkler, Lozan Antlaşmasından sonra mübadele yoluyla Anadolu'dan Yunanistan'ın çeşitli yerlerine getirilip yerleştirilen ve genel olarak Karamanlılar olarak bilinen Hristiyan Türkler ve Sovyetler Birliği'nin dağılmasından sonra, Gürcistan başta olmak üzere, Karadeniz çevresinden getirilen ve daha çok Batı Trakya'ya yerleştirilen Gürcistan Urumları veya Pontus Urumları denilen Hristiyan Türklerdir.

Çeşitli tarihî, siyasi ve kültürel amiller sebebiyle bu toplulukların Türk kimliği ve Türk dili karşısındaki algıları ve tavırları farklılıklar arz etmektedir. Yunanistan özelinde, Türk kimliğine aidiyet hissini, Türkçeden çok dinin, yani Müslümanlığın belirlediği görülmektedir. Türkçe konuştukları hâlde, Hristiyanlığın Ortodoks mezhebine mensup olan Karamanlılar, Urumlar ve Gagavuzlar arasında Türklük dairesine mensubiyet şuuru ya hiç yoktur veya çok zayıftır. Bilhassa, Gagavuzlar arasında, - Moldova, Ukrayna, Romanya ve Bulgaristan Gagavuzlarının aksine - çeşitli tarihî olayların bir sonucu olarak güçlü bir Türklük aleyhtarlığının var olduğu bilinmektedir. Beri taraftan Türkçenin oldukça zayıfladığı On İki Adalar Türkleri ve Türkçe dışında bir anadilleri olan Pomak Türkleri ve Müslüman Romanlar arasında çok köklü bir Türklüğe mensubiyet şuuru bulunmaktadır. Özellikle PomakTürkleri ve Müslüman Romanlar, geriye kalan Batı Trakya Türkleri ile birlikte, Yunanistan'da Türk hakları için çetin bir mücadele vermektedirler.

Türk kimliğine aidiyet hisleri farklılık arz eden bu topluluklar, Türkçe ile olan bağları dikkate alındığında bir ortaklık ortaya koymaktadırlar. Bütün bu toplulukların Türkçe ile bağları Oğuz Türkçesi üzerindendir. Osmanlı fethi sonrasında Yunanistan'a getirilip yerleştirilen Türklerin torunları, Gagavuzlar ve Karamanlılar Türkiye Türkçesinin ağızlarını konuşmaktadırlar. Aynı şekilde On İki Ada Türklerinin günümüzde unutmak üzere oldukları anadilleri de Türkiye Türkçesidir. Keza Pomak Türkleri ve Müslüman Romanların da ikinci dilleri Türkiye Türkçesinin ağızlarıdır ve kimlik kurguları da din ile birlikte bu dil üzerindendir. Gürcistan Urumları ise Azerbaycan Türkçesine benzer bir Türkçe konuşmaktadırlar. Görüldüğü üzere yedi grubun da konuştukları Türkçe Batı Oğuz Türkçesinin değişkeleridir. Ancak günümüzdeki bu manzaranın aksine, Yunanistan'da Türkçe her zaman Oğuz Türkçesi ile temsil edilmemiştir. Geçmişte Yunanistan'da Türkçe, Hun dilinden Bulgar diline, Peçenek dilinden Kuman diline kadar uzanan çok çeşitli değişkelerle temsil edilmiştir.

\section{Yunanistan ve Türkçe Konuşan Halklar: Kısa Bir Bakış}

Türkçenin Yunanistan'daki geçmişine bakıldığı zaman, gerek konuşulduğu coğrafya olsun gerek konuşurlarının etnik manzarası ve buna bağlı olarak diyalektik görünümü olsun 
gerekse sosyolengüistik durumu olsun, çeşitli tarihî devirlerde büyük farklılıklar arz ettiği görülmektedir. Türkçe, Yunanistan coğrafyasında zaman zaman yayılırken zaman zaman da gerilemiş, hatta yok olma noktasına gelmiştir. Kimi zaman yönetim dili olurken kimi zaman da ötelenen dil olmuştur. Bu yüzden Yunanistan'da günümüzde Türkçe konuşan toplulukları ve Türkçenin durumunu doğru kavrayabilmek için, Türk topluluklarının ve hâliyle Türkçenin Yunanistan'daki tarihî gelişim sürecine kısaca da olsa göz atmak faydalı olacaktır.

Yukarıda da zikredildiği üzere, tarihî seyir içerisinde Türkçenin Yunanistan'daki vaziyeti dönem dönem oldukça değişmiştir. Balkanların geriye kalanı gibi, günümüzde Yunanistan olarak adlandırılan coğrafya da birçok Türk halkının istilasına uğramıştır. Hunlarla başlayan bu istilalar, Avarlar, Ogurlar, Bulgarlar, Peçenekler, Uzlar, Kumanlar ve nihayet Osmanlılarla devam etmiştir. Bu Türk halklarının özelde Yunanistan ve genelde Balkanlar üzerindeki siyasi, toplumluk ve dolayısıyla dillik etkileri, bölgeye geliş tarzları ile doğrudan alakalı olarak çeşitlilik göstermiştir. Kimileri bölgeyi kısa süreliğine istila ve yağma ederken, kimileri fetih hareketlerine girişip bölgeye yerleşmiş ve uzun süre kalmışlar, kimileri de daha önce istilacı veya fatih olarak geldikleri bölgeye sığınmacı ya da esir olarak gelip yerleşmişlerdir. Tabiatıyla, Türk halklarının toplumluk statüleri ve kalış süreleri Türkçenin bölgedeki durumunu da belirlemiştir.

Hemen belirtmekte fayda var ki, Balkanları istila eden Hun, Avar, Ogur ve Bulgar Türkleri sık sık birbiri ile karıştırılmıştır. Bu karışıklığın iki sebebi vardır. Evvela, bu halklar birbirlerinin devletlerine tabi olmuşlardır. Mesela Ogur Türklerinin bir birliği olan Bulgar Türkleri, aynı zamanda Hun birliği içerisinde yer almaktaydı Keza, Avrupa'ya gelen Avarların bölgede bulunan bütün halklar gibi bu Türk boylarını da hâkimiyetleri altına aldıkları bilinmektedir. Dolayısıyla, istila hareketlerine umumiyetle birlikte girişmişlerdir. Bu da, istilaya uğrayanların istila edenlerin Hun mu, Bulgar mı, Avar mı olduklarını tespit etmelerini zorlaştırmıştır. Karışıklığa sebep olan bir diğer sebep ise, bu Türk boylarının hepsinin genellikle Bulgar Türkçesi olarak adlandırılan r-l Türkçesi konuşuyor ${ }^{1}$ olmaları yani birbirlerine sadece görünüş açısından değil dillik bakımdan da benzemeleridir. Bu karışıklıkların daha sonraki devirlerde Balkanları istila etmiş Genel Türkçe konuşan Türk toplulukları için geçerli olmadığı görülmektedir. Binaenaleyh, Türkçenin bölgedeki tarihini, Bulgar Türkçesi ve Genel Türkçe olarak iki bakımdan tetkik etmek doğru olacaktır. Aslında Türkçenin Balkanlardaki geçmişi umumi olarak ihmal edilmiş olmakla birlikte tarihî kayıtların da azlığı sebebiyle bilhassa Bulgar Türkçesi devri, Tuna Bulgar yazıtları üzerinde yapılan çalışmalar hariç, tamamen atıl bırakılmıştır. Bu çalışmada, bu devir boyunca Yunanistan'da, yani sınırları çizilmiş muayyen bir coğrafyada, Türkçenin durumu tespit edilmeye çalışılacaktır.

\section{Hun Devri}

Tarihî kayıtlarla kesin olarak tespit edilebilen Yunanistan'daki ilk Türk varlığı, Hunlar

1 Konuştukları dil bakımından oldukça büyük tartışmalara sebep olan Avrupa Avarlarının dillerinin bir Bulgar Türkçesi lehçesi olduğunu Rona-Tas (1996) sarih bir şekilde ortaya koymaktadır. 
döneminetekabületmektedir.GünümüzdeYunanistanolarakadlandırılanbölgeyidefalarca istila ettikleri görülen Hunların bölgedeki kayıtlı ilk varlığının 377 yılında, Balkanlar'da baş gösteren Got İsyanı esnasında olduğu bilinmektedir. Bir taraftan Romalıların emrinde olan ve Balkan dağlarındaki müstahkem geçitleri oluşturan limeslerde ${ }^{2}$ görevli olan Hun-Alan kıtaları Batı Gotları ile ittifak edip bütün Trakya'yı yakarken, diğer taraftan Hun birliklerinin Makedonya ve Trakya'da Doğu Gotları'nın kralı Viderik'i kovaladıkları kaydedilmiştir (Ahmetbeyoğlu, 2013a, s. 59; Hodgkin, 2001, C. 1, s. 140-142; Thompson, 2008, s. 41-42). 386 yılında Trakya'yı ziyaret eden Aziz Hypatius, Hun birliklerinin kırsal bölgelerde serbestçe dolaşıp her yeri yağmaladıklarını kaydetmiştir (Thompson, 2008, s. 55). Muhtemelen Balamir döneminde cereyan eden bu olaylardan sonra, doğrudan Doğu Roma'yı hedef alan ilk Hun saldırısı, 395 yılında Uldız dönemindedir. Doğu Roma ve Batı Roma'nın kendi aralarında savaşa tutuşmaları üzerine, Hunlar iki koldan Doğu Roma üzerine saldırıya geçmişlerdir. Basık ve Kursık Beyler komutasındaki bir kol Kafkaslar üzerinden Anadolu ve Suriye'ye saldırırken, Hunların Batı kanadı Tuna'yı geçip Moesia ${ }^{3}$ düzlüklerini zapt ederek buradan Balkanlara, İllirya'ya ${ }^{4}$ ve Trakya'ya kadar ilerlemişler ve buraları tahrip etmişlerdir (Ahmetbeyoğlu, 2013a, s. 67, 2013b, s. 129; Hodgkin, 2001, C. 1, s. 375; Meanchen-Helfen, 1973, s. 53; Thompson, 2008, s.43-44). Ancak, Bizans'a yöneltilen bu çift yönlü taarruzdan bir yıl evvel, Trakya'dan gelen Hun savaşçılarının Eugenius'a karşı I. Theodosius'u desteklediklerini Antakyalı loannnes kaydetmektedir (Sinor, 2000, s. 251). Bu Hun savaşçılarının Uldız'ın Hunları mı, yoksa Trakya'da yerleşmiş Bizans'ın emrindeki başka bir Hun grubu mu olduklarını günümüz itibarı ile tespit etmek pek mümkün görünmemektedir. Ancak İoannes'in bu Hun savaşçılarının kabile yöneticileri ile birlikte geldiklerini belirtmesi (Maenchen-Helfen, 1973, s. 49), bu Hunların Trakya'da yerleşik Hun kabilelerine işaret ettiği şüphesini uyandırmaktadır ki zaten 392 yılında, yine Theodosius'un rızasıyla Rufinus ile ittifak eden birtakım Hunların Trakya'ya yerleştiği bilinmektedir (Maenchen-Helfen, 1973, s. 48). 404-405'te Trakya'yı yeniden istila eden Hunlar, 408 yılında, Doğu Roma üzerine iyi örgütlenmiş ilk saldırıyı gerçekleştirmiş̧lerdir. Yine Uldız döneminde gerçekleşen bu saldırı neticesinde Hunlar, Trakya'yla Makedonya'yı yağmalamışlar ve müteakip bin yılda Bizans'ı koruyacak olan Anthemik Surunun inşasına sebep olmuşlardır (Ahmetbeyoğlu, 2013a, s. 75-76, 2013b, s. 136; Meanchen-Helfen ,1973, s. 63; Sinor, 2000, s. 255-256; Thompson, 2008, s. 46-47 ).

Uldız döneminde yağma akınları şeklinde olan Yunanistan'daki Hun hareketlerinin Rua döneminde istila hareketlerine dönüştüğü görülmektedir. Doğu Roma'nın iç karışıklıklar içerisinde olmasından ve doğuda İranlılar tarafından tehdit edilmesinden faydalanan Rua, 422 yılında Makedonya ve Trakya'yı istila etti. Rua'nın 430 ve 434 yıllarında iki kez daha

2 Roma İmparatorluğunda sınırları savunmakla görevli birliklerin bulunduğu müstahkem mevkiler (https:// www.britannica.com/technology/limes) (31 Ağustos 2018).

3 Sırbistan, Makedonya, Bulgaristan ve Romanya'nın Tuna nehrinin güneyinde kalan topraklarından oluşan Roma eyaleti (https://www.britannica.com/place/Moesia) (31 Ağustos 2018).

4 Balkan Yarımadasının batısında kalan Roma eyaleti (https://www.britannica.com/place/Illyria) (31 Ağustos 2018). 
Trakya'yı istila ettiği görülmektedir. Bu istilalar neticesinde Doğu Roma haraca bağlanmış ve sonuncu istilada İstanbul da tehdit edilmiştir (Ahmetbeyoğlu, 2013a, s. 81-82, 2013b, s. 139-140; Meanchen-Helfen, 1973, s. 76).

441 ve 442 'deki I. Balkan seferi esnasında, Bleda ve Atila kumandası altında bütün İllirya'yı ve Trakya'yı harap edip birçok şehri fetheden Hunları, 447 yılında, Atila'nın II. Balkan seferi sırasında yeniden Yunanistan topraklarında görmekteyiz. Bu sefer sırasında Hunlar, hemen hemen bütün Trakya şehirlerini fethettikten sonra, Teselya içlerine ilerleyerek Yunanistan'ın güneyindeki Thermopylae (Termopil Geçidi)'yi ele geçirmiştir. Bu sefer neticesinde İstanbul'un büyük bir tehdit altında kalması sebebiyle Romalılar Atila ile çok ağır şartlar altında Anatolius Barışı'nı imzalamak zorunda kalmışlardır (Ahmetbeyoğlu, 2013a, s. 108, 119, 2013b, s. 155; Hodgkin, 2001, C. 2, s. 33; Meanchen-Helfen, 1973, s. $111-$ 125; Levtechenko, 2007, s. 44; Mango, 2005, s. 22; Sinor, 2000, s. 262; Thompson, 2008, s. 120). Doğu Roma'yı Balkan seferleri ile haraca bağlayıp itaat altına aldıktan sonra, Atila'nın daha çok Batı Roma üzerine yoğunlaşmasına rağmen, 451 yılında Hunların yeniden, İllirya ve Trakya'yı istila edip yağmaladıkları görülmektedir (Meanchen-Helfen, 1973, s. 131).

Atila'nın ölümünden kısa bir süre sonra Hun siyasi birliğinin dağılması ile de Yunanistan'daki Hun varlığının sona ermediği görülmektedir. Bizans çeşitli Hun gruplarından askerî olarak faydalanmıştır. Mesela, birtakım Hun gruplarının Kelkal isimli bir şahsın kumandası altında, Magister Militum ${ }^{5}$ Flavius Ardabur Aspar'ın yönettiği Bizans ordusuna katılıp ordunun atlı birliklerini teşkil etmişlerdir (Ahmetbeyoğlu, 2013b, s. 183). 474 yılında tahta çıkan Zenon'un orduyu İsaurialı ve Ermeni askerlerle yeniden yapılandırmasına kadar, Bizans ordusunun yarısını Germenlerle birlikte Hunların oluşturduğu bilinmektedir (Levtchenko, 2007, s. 54). V. Yüzyılın sonunda başlayan Bulgar ve Slav akınları sebebiyle kıtlık baş göstermesi üzerine, Trakya'da ayaklanan foederati ${ }^{6}$ topluluklar arasında Hunların da bulunmuş (Levtchenko, 2007, s. 60) olmasına bakılacak olursa, Hunların Atila sonrası dönemde de Trakya'da yerleşik olarak bulundukları sonucuna varılabilir. Mesela, Hodgkin (2001, C. 3, s. 244) bu dönemde Hunların Balkanlar'daki Bizans ordusunun büyük kısmını teşkil ettiğini düşünmekte ve bu Hunların Sabir ve Tarrak adlı reislerin komutası altında, 514 yılında Trakya'yı, Moesia ile birlikte talan ettiklerini belirtmektedir. Dengizik'in Doğu Gotları tarafından mağlup edilmesinin ardından, birtakım Hun gruplarının Bizans'a sığınıp Sarmatlar ve Cemandierler ile birlikte İllirya'ya yerleştirildiğini Jordanes kaydetmektedir (Ahmetbeyoğlu, 2013a, s. 172).

540 yılında cereyan eden Bulgar ve Slav akınları sırasında, Hunların yeniden sahneye çıktığı görülmektedir. Bu Hunlar, Trakya, Makedonya ve Illirya'yı istila etmişler, Korint Kıstağı'na kadar ilerleyerek Yunanistan'ı talan etmişlerdir (Hodgkin, 2001, C. 4, s. 223;

5 Trakya Ordusu Başkomutanı (Levtchenko, 2007, s. 90)

6 Askerî hizmet karşılığında yarı bağımsız olarak yaşayan topluluklar. Bunlar Bizans devletine anlaşma ile bağlı olup ne Roma kolonisi ne de Roma vatandaşı olarak kabul edilmekte idiler. Ancak savaş zamanında askerî birlikler sağlamakla mükelleftiler. (https://www.princeton.edu/ achaney/tmve/wiki100k/docs/Foederati. html) (31 Ağustos 2018) 
Levtchenko, 2007, s. 90). Yukarıda zikredildiği gibi, V. Yüzyılın sonundan itibaren orduda hâkim unsurun İsauriali ve Ermeni askerlerin olmasına rağmen, İmparator Mavrikios'un (582-602) ordusunda, Lombardlar ve Bulgarlarla birlikte hâlâ Hunların da bulunduğuna dair kayıtlar mevcuttur (Charanis, 1959, s. 32).

\section{Avar Devri}

Avar döneminde Türklerin Yunanistan coğrafyasında Hun dönemine nazaran daha etkin oldukları görülmektedir. 579-587 yılları arasında, Avarların yönetimi altında Bizans topraklarına birçok 'barbar' akını olmakla (Charanis, 1959, s. 36) birlikte, en etkili saldırı 586 yılında gelmiştir ${ }^{7}$. Bu tarihler arasında, Mora Yarımadası en az on kez istila edilmiştir (Runciman, 1930, s. 23). 586 yılı öncesindeki akınların etkisi, Bizans'ın Illirya ve Trakya gibi batı eyaletleri ile bağını koparıp buralardan asker tedarik etmesini engellemekle kalmıştır (Charanis, 1959, s. 32). Ancak 586 yılında Avarların Slavlarla birlikte gerçekleştirdiği saldırıda, İllirya ve Trakya eyaletleri talan edildiği gibi, Makedonya, Teselya ve Mora Yarımadası da dâhil olmak üzere, bütün Yunanistan ele geçirildi. Bu akın sırasında, Singidunum (Belgrad), Viminacium (Kostolac), Durostorum (Silistre), Marcianopolis (Devnya) ve Anchialos (Pomorie) gibi Balkan şehirlerinin yanında, günümüzde Yunanistan'da yer alan Selanik ve Korint gibi şehirler de Slavların yardımıyla Avarlar tarafından istila edildi (Charanis, 1959, s. 37; Mangaltepe, 2013, s. 219-220; Mango, 2005, s. 24).

587 yılında Avarların Bizans'a yenilmesi üzerine, Avar akınları bir müddet durulmuş, ancak 592 yılında Avarlar tekrar saldırıya geçmişler ve Anchialos'a kadar ilerlemişlerse de yeniden yenilmişlerdir. 592-602 yılları arasında karşılıklı akınların devam etmesine rağmen, Bizans'taki iç karışıklıklar, Bizans'ın Avarları Balkanlardan atmasına mani olmuş, bilakis Avarlar Balkanlara iyice yerleşmişlerdir. Bilhassa, Selanik'in de istila edildiği 597 yılındaki Avar saldırısının çok şiddetli olduğu bilinmektedir. 602 yılında, İmparator Mavrikos'un Avarlar üzerine ordu sevk etme girişimine karşı, ordunun Phokas önderliğinde isyan edip başkente yürüyerek imparatoru devirmesi üzerine, Balkanlardaki Bizans - Avar-Slav mücadelesi tamamen Avarların ve onların yönetimindeki Slavların lehine sonuçlanmıştır. Balkanlar'da Bizans'ın hiçbir askerî ve siyasi varlığı kalmamış ve burada meskûn olan halklardan vergiyi Avarlar toplamaya başlamıştır (Hodgkin, 2001, C. 5, s. 262; Mangaltepe, 2013, s. 220-221; Szadeczky-Kardoss, 2000, s. 286-287, 290-291; Vryonis, 1981, s. 389). 587-602 yılları arasında, Trakya ve günümüz Bulgaristan toparlaklarında cereyan eden olaylarda Avarlar karşısında kısmi de olsa Bizans'ın başarılı olduğunun görülmesine rağmen, durumun Yunanistan coğrafyasında çok farklı olduğu anlaşılmaktadır. Zira Avarların, 587 yılında ele geçirdikleri Mora Yarımadasını 805 yılına kadar, iki yüz on sekiz yıl yönettiklerini Monemvasia Kroniği ile Evagrius, Efesli John ve Menander gibi tarihçiler kaydetmektedir (Charanis, 1950, s. 149-151, 1952, s. 347; Mango, 2005, s. 24; Szadeczky-Kardoss, 2000, s. 294). Trakya bölgesinde ise Avarlarla Bizanslılar arasındaki mücadelenin 626 yılında Avarların İstanbul'u kuşatması ve akabinde yenilmelerine kadar,

7 Bazı tarihçiler bu akının 589 yılında olduğunu söyler (Mangaltepe, 2013, s. 219). 
karşılıklı saldırılar şeklinde devam ettiği görülmektedir. Bu olaylar içerisinde, 610 yılından itibaren Adriyatik ve Ege denizleri arasındaki arazide üstünlüğü ele geçiren Avarların 617 yılındaki saldırısı, bu çalışmanın konusu itibariyle bilhassa ehemmiyet teşkil etmektedir. Avarlar, bu saldırıda Teselya, Epir ve Trakya'yı bir kez daha baştan başa istila etmişler ve yağmalamışlardır (Levtchenko, 2007, s. 126; Mangaltepe, 2013, s. 221-229; Whittow, 1996, s. 262-66;). 626 yılında Avarların mağlup olması sonucunda, Trakya'dan askeri güç olarak çekilmiş olmalarına rağmen (Mangaltepe, 2013, s. 228-229), bölgedeki Avar varlığının daha uzun süre devam ettiği anlaşılmaktadır. Zira 813 yılında Bizans'ın Trakya'daki topraklarını istila eden Bulgar Hanı Kurum Han, Slavlarla birlikte Avarları da yardıma çağırmıştır (Karatay, 2013b, s. 289). Zaten yukarıda zikredildiği gibi, Mora Yarımadasını 805 yılına kadar ellerinde tutmuş olmaları da bu durumu teyit etmektedir. Mora Yarımadasının kaybı sonrasında da Avar varlığının Trakya ve Teselya'da X. yüzyıla kadar devam ettiği yönünde kayıtlar mevcuttur (Levtchenko, 2007, s. 169).

\section{Ogur Devri}

Ogur Türklerinin Bizans ile ilk ilişkilerinin Atila'nın vefatından on yıl sonra, 463 yılı civarlarında başladığı, Priskos'un Saraogur, Ogur ve Onogurların Doğu Roma'ya elçiler gönderdiğini kaydetmesinden anlaşılmaktadır (Karatay, 2013a, s. 241). Ancak, günümüz Yunanistan coğrafyasını da şamil Ogur istilalarının çok daha geç döneme rastladığı görülmektedir. Kinyalon komutasındaki 12.000 Kutrigur'un, 551 yılında Gepidlerle birlikte, Bizans'a saldırdıkları ve bütün Balkanları işgal edip yağmaladıkları anlaşılmaktadır. Bu saldırının Bizans'ın teşviki ile Kutrigurların Sandilk komutasındaki Utrigurlar tarafından kılıçtan geçirilmeleri sonucunda bertaraf edilmesi üzerine, Kutrigurlardan 2000 ailenin Bizans hizmetine girip Trakya'ya yerleştikleri görülmektedir (Anzerlioğlu, 2002, s. 220; Golden, 2006, s. 115; Runciman, 1930, s. 8-9; Rasonyi, 1984, s. 5; Stepanov, 2010, s. 41; Üren, 2013, s. 262). Aynı on yılın sonunda Kutrigur saldırısının tekrarlandığı anlaşılmaktadır. Agathias tarafından, 558-559 yılında Zabergan isimli biri komutasında Kutrigurların büyük bir istila hareketine giriştikleri kaydedilmektedir. Kuvvetlerini ikiye ayıran Zabergan, bir taraftan Gelibolu'ya ve İstanbul'a kadar Trakya'yı istila ederken diğer taraftan Termopil Geçidine kadar Yunanistan'ı ele geçirmiştir (Charanis, 1950, s. 160; Hodgkin, 2001, C. 4, s. 355-360; Runciman, 1930, s. 9; Vryonis, 1967, s. 69). Kayıtlardan 641-642 yılları civarında da Balkanlarda büyük bir Ogur istilasının cereyan ettiği anlaşılmaktadır. Kievli İsodore, Kutrigurlar Yukarı Moesia ${ }^{8}$, Pannonia ${ }^{9}$, Dalmaçya ve İyonya Denizine kadar olan toprakları istila ederken Utrigurların İstanbul surlarına kadar olan bölgeyi ve Gelibolu Yarımadasını da içine alacak şekilde bütün Trakya'yı istila ettiklerini; Onogurların ise, Makedonya, Teselya, Yunanistan, Termopil Geçidi ve Korint'e kadar her yeri yağma ettiklerini ve Korint'i

8 Makedonya Cumhuriyeti ve Güney Sırbistan (https://www.britannica.com/place/Moesia) (31 Ağustos 2018).

9 Çoğunluğu bugünkü Macaristan'da olmak üzere Doğu Avusturya ve kısmen Hırvatistan, Sırbistan (Voyvodina), Slovenya ve Bosna-Hersek gibi Balkan ülkelerini içine alan Roma eyaleti (https://www. britannica.com/place/Pannonia) (31 Ağustos 2018). 
hiçbir çaba sarf etmeden ele geçirdiklerini kaydetmektedir. Kutrigurların ve Utrigurların püskürtülüp mağlup edildiği anlaşılmaktadır. (Setton, 1950, s. 502-503). Ancak, Korint şehrinin Onogurlardan ancak 657-658 yılında Bizanslılar tarafından geri alınabildiği (Setton, 1950, s. 522) dikkate alınırsa, Onogur istilasının diğerlerine göre daha kalıcı sonuçlarının olduğu anlaşılmaktadır.

\section{Bulgar Devri}

540 yılında Bulgar Türkleri Balkan Yarımadasını istila ettiler. Bütün Trakya, Makedonya, İllirya ve güneyde Korint'e kadar olan her yer yağmalandı (Charanis, 1952, s. 348; Vryonis, 1967, s. 68). Bulgar saldırısının 544 yılında tekrarlandığı ve bu saldırıdan bilhassa İllirya'nın büyük zarar gördüğü anlaşılmaktadır. Zira bu sırada, İtalya'da Vitalius'un ordusunda bulunan İlliryalılar, bu saldırıları sebep göstererek orduyu terk etmişlerdir (Hodgkin, 2001, C. 4, s. 310; Mangaltepe, 2013, s. 209). 578-585 yılları arasında, Bulgar Türklerinin Slavlarla birlikte, Avarlar adına, Selanik civarlarına ve Yunanistanın geriye kalanına akınlar düzenlediği görülmektedir (Charanis, 1952, s. 346). VII. yüzyılın ikinci yarısına gelindiğinde, birçok Bulgar Türkünün Trakya'ya yerleşmiş olduğuna şahit olunur (Treadgold, 2002, s. 134-135). 711 yılında İmparator Justinien'in ordusunda, Thrace ${ }^{10}$ ve Opsikion ${ }^{11}$ Temalarında ${ }^{12}$ konuşlandırılmış 3000 Bulgar askerinin olduğu görülmektedir (Anzerlioğlu, 2002, s. 220). VIII. yüzyılda, Bulgarların Makedonya üzerinden nüfuzlarını günümüz Yunanistan toprakları içine doğru yaymaya başladıkları görülür. Telering Han (768-777) Orta Makedonya'ya 12.000 kişilik bir ordu gönderip burada yaşayan Bulgar Türklerini ve Slavları kendine bağlamaya çalışmış ve Kardam Han (777-804) da Struma bölgesinde yaşayan kabileleri kendine bağlamak için bölgeyi işgal etmiştir (Feher, 1984, s. 51-52). 812 yılında Makedonya'daki kaleler Kurum Han önderliğindeki Bulgar Türklerine teslim oldu. Ertesi yıl ise Edirne alındı ve bütün Trakya yakıldı (Karatay, 2013b, s. 287-289). 846 yılında, Malamir Han döneminde, Kavkan İsbules kumandasındaki Bulgarlar, StrumaKarasu (Strimonas) ve Mesta Karasu (Nestos) nehirleri civarını istila ettiler. Bu istilaya karşııı olarak Bizanslıların Trakya'yı tahrip etmesi üzerine geriye dönen İsbules, dönüş yolu üzerinde, Doğu Makedonya'daki Kavala yakınlarında bulunan Filippi şehrini ve bugün Bulgaristan'da yer alan Filibe'yi Bulgar topraklarına katmıştır (Runciman, 1930, s. 88). X. Yüzyılın başlarında Bulgar toprakları Trakya ve Makedonya'nın derinliklerine, Selanik yakınlarına kadar uzanmakta idi (Levtchenko, 2007, s. 188). 1014 yılında Bulgar Hanlığının II. Basil tarafından yıkılmasından sonra, pek çok Bulgar'ın Teselya'daki kalelere yerleştirildiği bilinmektedir (Charanis, 1961, s. 148). Malamir Han'ın (831-836) Selanik seferi neticesinde Bulgarların Yukarı Makedonya'ya (aşağı yukarı bugünkü Yunan Batı Makedonyası ve

10 Güney Batı Balkanlarda bir Bizans themesi (https://wikivisually.com/wiki/Thrace_\%28theme\%29) (31 Ağustos 2018).

11 Kuzeybatı Anadolu'da bir Bizans themesi (https://wikivisually.com/wiki/Opsikion) (31 Ağustos 2018).

12 Mark Whittow, theme kelimesinin Türkçedeki 10,000 manasına gelen tümen kelimesinden geldiğini, kelimenin önceleri askerî birliği, X. yüzyıldan itibaren ise askerî birliklerin yerleştiği yerleri ifade ettiğini belirtmektedir (Whittow, 1996, s. 120-121). 
Makedonya Cumhuriyeti'nin güneydoğu köşesi) yerleşmeye başladıkları görülmektedir (Runciman, 1930, s. 87). Malamir'in Bulgar sınırlarını güneye doğru genişletme çabalarııın bir devamı olarak Persiyan Kavala'ya kadar ilerlemiş, 860 yılında ise Boris Han, sınırlarını Mora Yarımadasının hemen kuzeyinde yer alan Pindos Dağlarına kadar genişletmiştir (Feher, 1984, s. 54-55; Runciman, 1930, s. 92). Çar Simeon'un ölümüne kadar Kuzey Yunanistanın Bulgarların elinde kaldığı ve buradan Adriyatik kıyıları ile Mora Yarımadasına akınlar düzenleyip istila hareketlerinde bulundukları bilinmektedir (Runciman, 1930, s. 174). Yunanistan'daki Bulgar hâkimiyetinin Çar Samuel (997-1014) zamanında da devam ettiği görülmektedir. Ancak Samuel, daha çar olmadan önce, Komutopuli adı altında ülkeyi kardeşleri ile birlikte yönettiği sırada, Yunanistan coğrafyasında faal olmuştur. Daha 976 yılında Serez'e bir başarısız saldırıda bulunduklarını kaynaklar kaydeder. Edessa / Vodena'yı kendine merkez olarak seçen Samuel, buradan Trakya, Makedonya ve Adriyatik kıyılarına akınlarda bulunmuştur. 980'den itibaren ise Teselya'ya yöneldiği görülmektedir. Bilhassa Larissa'yı hedef almış ve 986 yılında bu şehirle birlikte bütün Teselya'yı ele geçirmiştir. Larissa'yı (Yenişehr-i Fener) üs olarak kullanan Samuel, buradan Tempe Vadisi, Termopil Geçidi ve Boeotia üzerinden Korint Kıstağına ve Mora Yarımadasına saldırılar düzenleyerek Bulgar hâkimiyetini Güney Yunanistan'a kadar genişletmiştir. Yunanistan'daki Bulgar hâkimiyeti, 1001 yılında, II. Basil'in başlattığı ve 1014 yılında Samuel'in ölümüyle neticelenen saldırılara kadar devam etmiştir (Runciman, 1930, s. 219-242).

\section{Tarihî Olayların Muhtemel Dillik Neticeleri}

Hunların siyasi ağırlığının daha kuzeyde, Pannonia'da olduğu dikkate alındığı zaman, Hunlar devrinde, Türkçenin genelde Balkan, özelde ise Yunanistan coğrafyasında pek etkin olmadığı, sadece akın ve istila dönemlerinde müstevlilerle birlikte bölgeye girip çıkan bir dil olduğu düşünülebilir. Hunların günümüzde Yunanistan olarak adlandırılan bölgelerde görülmeye başlandığı Balamir ve Uldız dönemlerinde bunun böyle olmuş olması pek muhtemeldir. Ancak daha 377 yılında, Balkan Dağlarındaki limeslerde Hun-Alan kıtalarııın bulunmuş olması, Hun Türkçesinin en azından asker dili olarak bölgede bulunduğuna delalet eder. Tabii ki bu durum, aynı zamanda daha güneyde de Romalılar tarafından yerleştirilmiş Hun topluluklarının veya konuşlandııımış Hun askerlerinin olabileceğine işarettir. Ancak bu ihtimalin tarihî gerçeklikle ne kadar uyuştuğunu tespit etmek, günümüz itibarıyla pek mümkün görülmemektedir. Yine de Antakyalı loannes'in kaydettiği, Eugenius'a karşı I. Theodosius'u desteklemek için Trakya'dan gelen Hun savaşçıları meselesi ve özellikle Rufinus'un 392 yllında Trakya'ya yerleştirdiği Hunlar gerçeği bu intimali güçlendirmektedir. Meanchen-Helfen (1973, s. 51), Trakya'ya yerleştirilen bu Hunların yalnız yaşamak istemeyecekleri için, ailelerini ve sürülerini de getirttiklerini düşünmektedir ki; bu akla yatkın intimal, Trakya'da Türkçeyi sadece bir asker dili olmaktan çıkarıp cemiyet dili hâline getirmektedir. Hunların bölgedeki nüfuzlarını artırmaya başladıkları Rua döneminde ve bilhassa bölgeye iyice yerleştikleri Atila'nın II. Balkan Seferinden sonra, siyasi ve askerî gelişmelere koşut olarak Türkçenin de bölgedeki etkinliğinin artmış olması gerekir ki kayıtlarda bunun böyle olduğuna dair bazı işaretler mevcuttur. Mesela, Hun bürokrasisinin 
tepesinde bulunan iki kardeş olan ve Pontus çevresinden gelen Helenleşmiş barbar oldukları düşünülen Onegesios ve Scottas'ın Latince ve Yunancanın yanında Hun dilini de çok iyi biliyor (Ahmetbeyolu, 2013a, s. 111) olmaları, Hun Türkçesinin bu devirde Yunanca ve Latince gibi uluslararası etkinliğe sahip bir dil hâline geldiğinin bir delili olmalıdır. Uluslararası etkinliğe sahip Hun Türkçesinin, Hun devletinin hâkimiyeti ve nüfuzu altındaki bölgelerde yaşayanlar üzerinde etki yapmamış olması düşünülemez. Bu iki kardeşin istisna olmadığı da anlaşılmaktadır. 448 yılında Atila tarafından Doğu Roma'ya gönderilen elçilik heyetinde bir Hun olan Edekon ile birlikte Roma kökenli olup Atila'nın hizmetinde çalışan Orestes de bulunmaktadır (Ahmetbeyoğlu, 1995, s. 29; Hodgkin, 2001, C. 2, s. 35). Bu elçilik heyetinin dillik açıdan bir diğer dikkate şayan yönü, Orestes'in varlığına rağmen, Edekon'un meramını Hun dilinde aktarmış olması ve söylediklerinin Bigila tarafından tercüme edilmesidir (Ahmetbeyoğlu, 1995, s. 30) ki bu durum Hun devletinin Doğu Roma karşısındaki siyasi üstünlüğünün neticesinde Hun Türkçesinin de uluslararası anlaşma dili olarak Yunancanın ve Latincenin önüne geçtiğine işaret eder. Hun dilinin yabancılar tarafından konuşulduğuna dair bir diğer misal, yine Priskos tarafından kaydedilen İtalya'dan gelmiş olan Rusticus'tur (Ahmetbeyoğlu, 1995, s. 34). Yine Priskos'un kaydettiği Hun merkezindeki saçını Hunlar gibi kesmiş, Hun yöneticileri gibi giyinmiş Yunanlı örneği de oldukça ilginçtir (Ahmetbeyoğlu, 1995, s. 41; Thompson, 2008, s. 145). Bu durum, en azından Hun hâkimiyeti altındaki bölgelerde Hun Türkçesinin konuşma dili olarak Yunancanın önüne geçmiş olduğuna delalet eder. Zira Hun topraklarında, sadece Yunanistan'dan getirilen esirler tarafından konuşulan bir dil olduğu yine Priskos tarafından ifade edilen Yunancayı konuşarak bu Yunanlının Hun devletinde yöneticilik yapmış olması düşünülemez. Bu Yunanlının saçlarını Hunlar gibi kestirip Hunlar gibi giyinmesi de dikkate alınması gereken bir husustur. Zira bu tavır, tarih kitaplarında yaygın bir şekilde zikredildiği gibi, Hunların muhatap oldukları herkes tarafından insan dışı vahşi varlıklar olarak görülmediğine, bilakis Hun hayat tarzının imrenilip taklit edilen bir hayat tarzı olduğuna işaret eder.

Tekrar dil konusuna dönülecek olursa bilhassa Hun yönetimi altındaki bölgelerde yaşayan soylular üzerinde Hun Türkçesinin oldukça etkili olmuş olması gerekir. Zira soylu sınıf Hun devlet mekanizması ile istilaya uğramış halk arasında aracı rolünü görmüş olmalıdır. Bu, Hun Türkçesinin Yunanistan coğrafyasında Yunancayı ve Latinceyi ortadan kaldırdığı manasında yorumlanmamalıdır. Zira gerek demografik gerekse dinî ve siyasiaskerî sebeplerle bu iki dilin yerinin oldukça sağlam olduğuna şüphe yoktur. Ancak, yukarıda zikredilen örneklerden de anlaşılabileceği gibi, en azından yönetilenlerle yönetenler arasındaki bağı oluşturan soylu kesimler arasında Hun Türkçesi yayılmıştır. Hem de bu yayılmanın Latince ve Yunanca gibi çok köklü yazılı ve siyasi geleneğe sahip iki dile rağmen gerçekleşmiş olduğu, Hun siyasi gücünün ve dolayısı ile Hun Türkçesinin kazandığı itibarı anlayabilmek bakımından gözden kaçırılmaması gereken ehemmiyetli bir husustur.

Hun devletinin askerî ve dolayısıyla siyasi gücünün zayıflamasından veya devletin dağılmasından sonra, Hun Türkçesinin durumunun ne olduğu meselesi akla gelebilecek sorulardan biridir. Hun merkezî gücünün zayıflamasının ardından birtakım Hun kümelerinin 
Bizans'ın hizmetine girdiği veya günümüzde Yunanistan'ı oluşturan coğrafyayı da kapsayan Bizans arazisine iskân edildikleri yukarıda zikredilmişti. Bu Hun kümelerinin hızlı bir şekilde dillerini kaybedip Hristiyanlaştıkları ve eridikleri düşünülebilir. Zaten, tarih boyunca Bizanslılaşmanın veya Helenleşmenin en önemli üç unsurunun Rum Ortodoks Kilisesi, ordu ve bu iki kurumun kullandığı dil olan Yunanca olduğu kanısı mevcuttur (Mango, 2005, s. 2627; Vryonis, 1986). Özellikle Ortodoks Kilisesi, Yunancanın birçok topluluğa nüfuz etmesine sebep olmuştur. O yüzden durumun bu Hunlar için de aynı olmuş olması akla yakın gelmektedir. Meseleyle alakalı doğrudan kaynak bulunmamakla birlikte, var olan bilgilere dikkatlice bakıldığı zaman, durumun hiç de böyle olmadığına dair önemli işaretler vardır. Mesela, 536 yılında, merkezde konuşlanmış olan Bizans hizmetindeki Hun askerlerinin dahi İstanbul sokaklarında yollarını bulabilecek kadar bile Yunanca konuşamadıklarına dair kayıtlar mevcuttur (Hodgkin, 2001, C. 4, s. 16-17). Bu durum göz önünde bulundurulduğu zaman, Hun devleti güçten düşüp dağıldıktan sonra, Hun Türkçesinin, uluslararası etkinliğini kaybetmiş olmakla birlikte, daha uzun süre varlığını devam ettirdiği anlaşılır. Keza, kendisi Ortodoks olan Belisarius'un ordusunda bulunan Hunların Hristiyan olmayıp kendi dinlerini korudukları da kayıtlıdır (Hodgkin, 2001, C. 4, s. 40, 148-149) ki bu durum dil kaybının önündeki en büyük engel olmuş olmalı. Zaten, Ortodokslaşmanın da asimilasyon yönünde ehemmiyetli bir aşama olmakla birlikte, iddia edildiği kadar dil üzerinde etkili olmadığına işaret eden durumlar mevcuttur. Mesela, 518 yılında, İstanbul'da bulunan bir manastırın baş keşişinin Yunanca bilmediği için bir dilekçeyi imzalayamadığı kayıtları mevcuttur (Mango, 2005, s. 23) ve bunun bir istisna olduğunu düşünmeyi gerektirecek herhangi bir durum da yoktur. Zira Yunancanın en güçlü olduğu yapılardan biri, belki de birincisi, olan Ortodoks kilisesine ait bir kurumda, hem de Elen kültürünün en güçlü olduğu yerlerden birisi olan başkentte bile Yunanca bilmeyen bir baş keşişin bulunuyor olması, başlı başına bir olgunun yansımasıdır zaten. İstanbul'da dahi Hunların dillerini korudukları düşünülecek olursa Trakya, Makedonya ve Illirya gibi merkeze daha uzak ve sık sık istilaya uğrayan eyaletlerde Hun Türkçesinin daha uzun süre varlığını devam ettirdiğini ileri sürmek çok iddialı olmayacaktır. Hele eyalet merkezlerinden uzak, Hunların aileleri ile birlikte cemiyet hâlinde yaşadıkları bölgelerde, muhtemelen dil kaybı hiç gerçekleşmemiş ve Bulgar Türkleri bölgeye hâkim olana kadar Hun Türkçesi konuşulmaya devam etmiştir. Zaten kendisi de Bulgar Türkçesi türünden bir lehçe olan Hun Türkçesi muhtemelen daha sonra Bulgar Türkçesi ile aynı kaderi paylaşmıştır.

Avar döneminde Türk dilinin durumunun ne olduğunu tespit etmek, Hun dönemine göre çok daha çetrefilli görünmektedir. Avarlar, Hunlara göre Balkan Yarımadasında ve bilhassa Yunanistan'da daha etkin olmakla birlikte, kaynakların eksikliği bu konuda bir hüküm vermeyi çok zor hâle getirmektedir. Mesela, Avarların sadece Bizans'la değil Lombardlar ve Franklarla da diplomatik ilişkiler içerisinde bulunduğu (Szadecky-Kardoss, 2000, s. 290), hatta kısa süreliğine de olsa Bizans ile Avarlar arasında bir ittifakın kurulmuş olduğu ve bu ittifakın bir neticesi olarak 578 yılında 60.000 Avar askerinin kağana vergi vermeyi reddeden Slavların Aşağı Tuna bölgesindeki yurtlarına sefer yaparken Bizans gemileri ile 
taşındığı (Obelensky, 1997, s. 74; Szadeczky-Kardoss, 2000, s. 286) bilinmektedir. Ancak, Hunların sosyal hayatı ve Hun - Doğu Roma ilişkileri hakkında çok değerli bilgiler sağlayan Priskos gibi bir kaynağın bu dönemde bulunmaması, dönemin dillik açıdan manzarasının karanlık kalmasına sebep olmaktadır. Yine de Efesli İoannes'in Kilise Tarihi'nde, Menandros Protektor'un eserinin bazı kısımlarında ve Theophylakos Simokattes'in eserinde yeri geldikçe Avarlardan bahsetmesi, araştırmacıları tamamen karanlıkta kalmaktan kurtarmaktadır. Biri 558 yılında, diğeri 562 yılında olmak üzere Avarların Bizans'a iki elçilik heyeti gönderdiği bilinmektedir (Karatay, 2004, s. 28-30). Ancak bu elçilik heyetinin diplomatik ilişiklerini hangi dilde yürüttüğünü tespit etmek mümkün değil. Gelenlerin kılıklarının tarifinden Avar oldukları anlaşılmakla beraber, ilişkilerin Avar dilinde yürütüldüğünü düşünmek doğru olmaz. Zira bu tarihlerde Avarlar, Bizans'tan yerleşmek için toprak talep etmektedirler. Ancak Avarların Balkanlarda nüfuzlarını artırmaları ile Türkçenin durumunun da değiştiği düşünülebilir. 588 yılında ele geçirilen Mora Yarımadasından yerli halkın sürüldüğü ve yerlerine Avarların ve Slavların yerleştiği anlaşılmaktadır. Vryonis (1967, s. 69-79) bu istila neticesinde Trakya ve Yunanistan'ın esaslı bir etnografik değişim geçirdiği, Bizans ve Hristiyan medeniyetine dair her şeyin yok olduğu görüşündedir. Gerçekten de Monemvasia Kroniği "lyi Rumların” sürüldüğünü, imha edildiğini, yerlerine kendilerinin yerleştiğini, "katillerin" ellerinden kaçabilenlerin çeşitli yerlere dağıldıklarını kaydeder. Yine aynı kronik, sadece Slavların elinde olan yarımadanın doğu kesimlerinin ulaşılması zor olduğu için özgür olduğunu kaydetmektedir (Davidson ve Horvath, 1937, s. 228). Bu istila neticesinde Mora Yarımadasının nüfusunun Slavlaştığı kanısı yaygındır. Ancak bu ifadeden yarımadanın batı kesimlerinin Avarların ellerinde olduğu anlaşılmaktadır. Gerçekten de bu istila sebebiyle İtalya ve Sicilya'ya kaçan Rumlar, kendilerini sürenlerin Avarlar olduğunu ifade etmişler, Slavlardan bahsetmemişlerdir (Curta, 2004, s. 68) ${ }^{13}$. Fakat IX. ve X. yüzyıllarda Mora Yarımadasının tekrar Hristiyanlaşmasını konu alan kaynaklar, Avarlardan hiç bahsetmezler ve yarımadanın batısında "Slavlardan, tanassur yolu ile Rumlar yaratıldığından" bahsederler (Dunn, 1977, s. 71-86). Bundan hareketle iki üç asır içerisinde Avarların Slavlaştığı sonucuna varılabilir. Ancak bazı Yunan kaynaklarında Avarların Slavlarla karıştıııldıkları görülmektedir. Mesela Aziz Pankraitos'un Biyografisinde 750'li yıllarda Atina civarında yaşayan Avarların Slavlar olarak adlandırıldığı yazmaktadır (Rasonyi, 1984, s. 11). Bu kayıtlardan anlaşılmaktadır ki 588 yılındaki istiladan sonra Yunanistan coğrafyasına Avar grupları yerleşmiştir. Bu da Avarların konuştuğu Türkçenin bir cemiyet dili olarak bu coğrafyada kullanıldığı anlamına gelmektedir. Bununla birlikte, Slavların yerleştiği bölgelerde de Avar Türkçesinin yönetim dili olduğu düşünülebilir. Gerçekten de Avarların işgal ettikleri bazı bölgelerde toprakların işlenmesi için Slavları iskân ettiklerini kaynaklar kaydeder (Rasonyi, 1984, s. 9). Nitekim 58788 sonrasında Mora Yarımadasında meydana gelen istiladan bahseden kaynaklar, bunun Avar - Slav istilası ya da Avarlar tarafından yönlendirilen Slavların bir istilası olarak zikrederler

13 Bu bölgede yoğun bir Avar nüfusunun olduğunu ispatlayan birtakım yer adları da mevcuttur. Mesela günümüzdeki adı Pylos olan Mora Yarımadasındaki şehrin eski ismi olan Navarin/Navarino adının Yunanca Eis Tôn Avarinon "Avarlardan gelme" deyiminden çıktığı kaydedilmektedir. Yine bugün Karadağ'da kalan daha kuzeydeki Antivari şehrinin eski adı Civtas Avarorum "Avarların şehri" idi (Rasonyi, 1984, s. 11). 
(Charanis, 1952, s. 343; Mango, 1980, s. 24, 97; Vryonis, 1981). Bu durumdan da Slavların en azından yönetici sınıflarının Avar Türkçesini anlayıp konuştukları sonucu çıkarılabilir. Netice olarak anlaşılmaktadır ki Avar Türkçesi Vl. yüzyıldan itibaren Yunanistan coğrafyasında hem yönetim dili hem de cemiyet dili olarakkullanıımıştır. Ancak bu dilin varlığını nezamana kadar devam ettirdiğini söylemek mümkün değil. Yine de bilgi kırıntıları üzerinde düşünüldüğü zaman Avar Türkçesinin en azından VIII. yüzyıla kadar Yunanistan'da varlığını devam ettirdiği düşünülebilir. Mesela 750 yılında Atina civarında Avarlardan bahsedilmesi, Avar dilinin de bu tarihte hâlâ konuşulduğu şeklinde yorumlanabilir. Keza kaynakların Telering Han'ın (768-777) Orta Makedonya'da bulunan Bulgarları ve Slavları kendine bağlamak için sefer düzenlediğinden bahsetmesi, bu Bulgarların hâlâ Slavlaşmadığını gösterir. Bu da Türkçe konuşan toplulukların Slavlar arasında varlıklarını bu tarihte hâlâ devam ettirdiklerinin bir işaretidir. Dolayısıyla pek muhtemeldir ki en azından bazı bölgelerde aynı Hun Türkçesi gibi Avar Türkçesi de dil kaybı olmaksızın Bulgar Türkçesi ile birleşmiştir.

VI. ve VII. yüzyıllarda Ogur Türklerinin Balkan coğrafyasında Yunanistan'a kadar uzanan birçok istila hareketine girişmiş olmasına rağmen, dillerinin umumi olarak Balkanlar'da ve hususi olarak Yunanistan'da ne gibi etkiler yaptığını tespit etmek çok zordur. Bu zorluğun birkaç sebebi vardır. Her şeyden önce kaynak yetersizliği bu konuda sağlıkı bir yorum yapmaya izin vermemektedir. Bir diğer önemli sebep ise, daha önce de zikredildiği üzere, Hunları, Avarları, Ogurları ve Bulgarları dil bakımından ayırt etmenin pek mümkün olmamasıdır. Ancak şüphesiz bu benzerlik, en azından mahalli olarak bu coğrafyada bulunan Ogur öncesi Hun varlığını pekiştirirken kendileri ile eş zamanlı ve kendilerinden sonra cereyan eden Avar ve Bulgar istilalarının dil bakımından etkilerinin pekişmesine zemin hazırlamıştı. Yine de kırıntı hâlindeki tarihî kayıtlar birtakım ipuçları sağlamaktadır. Mesela 551 yilında cereyan eden olaylar neticesinde 2000 Kutrigur ailesinin Trakya'ya yerleşmesi sonucunda Ogur Türkçesinin Kutrigurlar tarafından konuşulan şeklinin burada en azından bir cemiyet dili olarak kullanılmaya başladığının bir delili olarak kabul edilebilir. Aynı on yılın sonunda cereyan eden Zabergan komutasındaki Kutrigur istilasının bu durumu pekiştirdiği ve Ogur Türkçesinin toplumluk itibarını ve işlevini artırdığı düşünülebilir. Ancak şüphesiz Ogur Türkçesi Yunanistan'daki en etkin konumuna 641-642 yıllarında gerçekleşen birleşik Ogur saldırısı neticesinde kavuşmuştur. Bu istila hareketi neticesinde günümüz Yunanistan coğrafyasının tamamı Onogurların eline geçerken bilhassa Korint şehrinin yirmi yıla yakın Onogurların elinde kaldığı düşünülürse Ogur Türkçesinin burada yönetim dili hâline geldiği görülmektedir. Fakat bu şehrin Ogurların eline geçmesinin esas önemini bulunduğu yer teşkil etmektedir. Bu şehrin 587-805 yılları arasında Avarların elinde bulunan Mora Yarımadası ile anakara Yunanistan'ı birbirinden ayıran noktada bulunduğu unutulmamalıdır. Yani 220 yıldan fazla Türkçenin yönetim ve muhtemelen cemiyet dili olduğu bir coğrafyanın hemen sınırındaki bir şehirde de Türkçe yönetim dili hâline gelmiştir. Üstelik hem Mora'daki hem de Korint'teki Türkçenin aynı lehçe özelliklerini (r-I Türkçesi) gösteren Türkçeler olduğu düşünüldüğü zaman meydana gelen toplumluk etki daha iyi anlaşılmaktadır. 
Bu dönemde Balkanlar'da cereyan eden Türk fetih ve istilalarının en etkilisi şüphesiz Bulgar Türklerininkidir. Bulgarlar Balkanlar'ı sadece istila etmekle kalmamış, sonuçları günümüze kadar etki edecek şekilde bu coğrafyayı vatan hâline getirmişlerdir. 540 yılında Balkan Yarımadası'nda ilk görülmelerinden itibaren 1014 yılında yıkılana kadar ve yıkıldıktan sonra bu coğrafyanın etnik yapısına ve dolayısıyla dillik manzarasına birçok kere farklı derecelerde etki yapmışlardır. 540 ve 544 yıllarında cereyan eden istila hareketlerinin kalıcı sonuçları olmaması sebebiyle bölgeye dil bakımından bir etki yaptıklarını söylemek zordur. Ancak 578-585 yılları arasında Slavlarla birlikte Avarlar adına gerçekleştirdikleri saldırıların bir sonucu olarak Yunanistan'ın Bizans ile bağının kopması neticesinde, birtakım Slavlarla birlikte Bulgar Türklerinin de Yunanistan'ın çeşitli bölgelerine yerleştikleri düşünülebilir. Eğer bu varsayım doğru ise VI. yüzyıldan itibaren Bulgar Türkçesi Yunanistan'da bir cemiyet dili hâline gelmiş demektir. Fakat bunu doğrulayacak veriler elde yoktur. AncakVII. yüzyılın ikinci yarısında birçok Bulgar Türkünün Teselya'ya yerleştiğinin kaydı mevcuttur. Bu demektir ki bu tarihten itibaren Bulgar Türkçesi Yunanistan'da bir cemiyet dili olmuştur. 711 yılında ise 3000 Bulgar askerinin Thrace ve Opsikion Temalarında konuşlandırılması üzerine, Bulgar Türkçesi, Bizans sınırları dâhilindeki Yunanistan coğrafyasında ordu dili hâline de gelmiştir. Müteakip yüzyıllarda Tuna Bulgar Hanlığının hâkimiyetinin Yunanistan'a yayılmasına koşut olarak Bulgar Türk nüfusunun da arttığı ve dolayısıyla Bulgar Türkçesinin hem konuşulduğu alanın büyüdüğü hem de toplumluk itibarının arttığı düşünülebilir. Nitekim 831-836 yılları arasında Malamir Han’ın gerçekleştirdiği Selanik seferi neticesinde bugünkü Yunan Makedonyası'nın batısını da içine alan Yukarı Makedonya'ya birçok Bulgar yerleşmiştir. Boris Han'ın Yunanistan'daki Bulgar hâkimiyetini Mora sınırına kadar genişletmesi ve bu durumun 1014 yılında Tuna Bulgar Hanlığının yıkılmasına kadar devam etmesi sonucunda, Bulgar nüfusunun da Mora sınırına kadar yayıldığı düşünülebilir. Hatta Yunanistan'da Bulgar yayılmasının Bulgar Hanlığının 1014 yılında yıkılmasından sonra da devam ettiği görülmektedir. 1014 sonrasında birçok Bulgar'ın Teselya'daki kalelere yerleştikleri daha önce zikredilmişti. Ancak maalesef Bulgar nüfusunun yayılmasına koşut olarak Türkçenin nüfuzunun da yayıldığını söylemek mümkün değil. Zira Bulgarların arasında Hristiyanlığın yayılmasıyla birlikte Slavlaşmanın da başladığı ve IX. yüzyıldan itibaren Bulgarların tamamen Slavlaştığı görüşü genel kabul görmektedir (Golden, 2006, s. 297-298; Feher, 1984, s. 87; Kafesoğlu, 1985, s. 32; Karatay, 2013b, s. 294; Kayapınar, 2013, s. 111; Rasonyi, 1984, s. 27). Ancak bunun umumi bir durum olmadığına dair ciddi işaretler mevcuttur. Dimitrov (1993), bir Bulgar kroniğine dayanarak XII. yüzyıla kadar Tuna nehri boyunca Türkçe konuşan bir Bulgar tabakasının mevcudiyetini ortaya koymuştur. Keza Hristiyan olup Knez Mihail adını alan Boris Han'ın oğlu Vladimir, muhtemelen kendini destekleyen bir nüfusa güvenerek tahta geçtikten sonra Hristiyanlığı bırakıp eski Türk dinine dönmüştür (Karatay, 2013b, s. 294). Bu durum, Slavlaşmanın genel kanının aksine umumi bir durum olmadığını göstermektedir ki bu da Türk dilinin de birtakım Bulgarlar arasında yaşıyor olması gerektiği manasına gelir. Görülmektedir ki birtakım Bulgarlar Slavlaşırken birtakım Bulgarlar eski Türk geleneklerini ve Türk dilini XII. yüzyıla kadar yaşatmışlardır. 
Hakeza, Yunanistan coğrafyasında da bazı Bulgar gruplarının Türkçeyi koruduklarını varsaymak yanlış olmayacaktır. Bilhassa önceki Hun, Avar ve Ogur istilaları neticesinde Yunanistan coğrafyasına yerleşen Türklerin bulunduğu bölgelerde Bulgar Türkçesinin bir süre daha cemiyet dili veya en azından hane içi konuşma dili olarak varlığını devam ettirdiği düşünülebilir.

\section{SONUÇ}

IV.-X. yüzyıllar arasında dalgalar hâlinde, umumi olarak Balkanlara ve hususi olarak Yunanistan'a, önce akınlar düzenleyip sonra gelip yerleşen Hun, Avar, Ogur ve Bulgar Türkleri hiç şüphesiz kendileri ile birlikte dillerini de getirmişlerdir. Her dört topluluğun dili de (Eski) Bulgar Türkçesi, Hun-Bulgar Türkçesi veya Eski Batı Türkçesi adlarılla anılması adet hâline gelmiş Türk lehçe grubuna mensup değişkeler olması sebebiyle birbirine zemin hazırlamış veya birbirini pekiştirmiştir. Bu dönemde Türkçe, Yunanistan'a bazen istilacı dili olarak girmiş, bazen de sığınmacı veya yerleşimci dili olarak girmiştir. Bazen cemiyet dili olurken bazen sadece ordu dili olarak kalmıştır, bazen ise yönetim dili hâline gelmiştir.

Hun devrinde, devletin gücüne koşut olarak Türkçenin Latince ve Yunancayı geride bırakarak uluslararası iletişim ve diplomasi dili hâline geldiği görülmektedir. Hun devleti gücünü kaybedip dağıldıktan sonra ise bu sefer Türkçenin varlığını Yunanistan coğrafyasında yerleşimci ve ordu dili olarak devam ettirdiği tarihî kayıtların ortaya koyduğu delillerle sabittir. Elde Hun devrine göre verilerin daha az olmasına rağmen, Avarların Yunanistan'daki hâkimiyetlerinin Hun devrine nazaran daha sağlam ve daha uzun olması sebebiyle, Türk dilinin de daha sağlam bir yere sahip olduğu düşünülebilir. Bilhassa Mora Yarımadası uzun süre Avarların elinde kalmıştır. Avarlardan kalan yer isimleri de Avar döneminde Hun dönemine kıyasla daha etkin bir Türk unsurunun ve dolayısıyla Türk dilinin mevcut olduğunun bir delilidir. Muhtemelen Avarlar kendi dillerine benzer bir Türkçe konuşan Hun kalıntılarını da Yunanistan'da bulup bünyelerine almışlardır. Üstelik Hun devleti dağıldıktan sonra Avarlardan hemen önce bazı Ogur grupları Yunanistan'a gelip yerleştiği gibi Avarlarla birlikte de birtakım Ogur ve Bulgar gruplarının Yunanistan'a girip yerleştiği bilinmektedir. Bütün bunlar Avar döneminde Yunanistan'da zaten yönetim dili olan Türk dilinin durumunu cemiyet dili olarak da takviye etmiş olmalı. Avarların Slavların içerisinde eridikleri kanısı yaygın olmakla birlikte en azından mahalli olarak bunun gerçekleşmediğine dair bazı deliller mevcuttur. Pek muhtemeldir kiYunanistan'ın bazı bölgelerinde Avarlar dillerini kaybetmeden kendilerini müteakip bütün Balkanları hâkimiyetleri altına alan Bulgar Türklerine katılmışlardır. Bulgar Türklerinin Avarlardan devraldıkları bütün Slavları yönetme hedefleri neticede beş-altı asır boyunca tekâmül etmiş olan bir Türk topluluğunun, dolayısıyla Türk dilinin, ortadan kalkmasına sebep olmuştur. Hun - Avar - Bulgar devrinin Yunanistan Türkleri önce Slavlaşmış sonra da Yunanistan'ın yeniden Bizans hâkimiyetine girmesiyle büyük oranda Rumlaşmıştır. 


\section{KAYNAKÇA}

Ahmetbeyoğlu, A. (1995). Grek seyyahı Priskos (V. asır)'a göre Avrupa Hunları. İstanbul: Türk Dünyası Araştırmaları Vakfı.

Ahmetbeyoğlu, A. (2013a). Avrupa Hunları. İstanbul: Yeditepe.

Ahmetbeyoğlu, A. (2013b). Avrupa Hunları. O. Karatay \& S. Acar (Ed.), Doğu Avrupa Türk tarihi içinde (s. 107-187). İstanbul: Kitabevi.

Anzerlioğlu, Y. (2002). Bizans İmparatorluğu'nda Türk varlığı. H. C. Güzel, K. Çiçek \& S. Koca (Ed.), Türkler içinde (C. 6, s. 218-232). Ankara: Yeni Türkiye Yayınları.

Baker, D. (Ed.). (1977). Renaissance and renewal in Christian history: Papers read at the fifteenth summer meeting and the sixteenth winter meeting of the Ecclesiastical History Society. Oxford, UK: Blackwell.

Charanis, P. (1950). The Chronicle of Monemvasia and the question of the Slavic settlements in Greece. Dumbarton Oak Papers 5, 141-166.

Charanis, P. (1952). On the capture of Corinth by the Onogurs and its recapture by the Byzantines. Speculum 3, 343-350.

Charanis, P. (1953). A Note on the population and cities of the Byzantine Empire in the thriteenth century. In The Joshua Starr memorial volume: Studies in history and philology (pp. 135-148). New York, NY: Conference on Jewish Relations.

Charanis, P. (1959). Ethnic changes in the Byzantine Empire in the seventh century. Dumbarton Oak Papers 13, 23-44.

Charanis, P. (1961). The transfer of populations as a policy in the Byzantine Empire. Comparative Studies in Society and History 3(2), 140-154.

Curta, F. (2004). The making of the Slavs. History and archaeology of the Lower Danube region c. 500-700. Cambridge, UK: Cambridge University Press.

Davidson, G. R., \& Horvath, T. (1937). The Avar invasion of Corinth. Hesperia: The Journal of the American School of Classical Studies at Athens 6(2), 227-240.

Dimitrov, S. (1993). The Bulgarian apocryphal chronicle and Bulgarian ethnic history. Etudes Balkaniques 29(4), 97-109.

Dunn, M. (1977). Evangelisatıon or repentance? The re-Christianisation of the Peloponnese in the ninth and tenth centuries. In D. Baker (Ed.), Renaissance and renewal in Christian history: papers read at the fifteenth summer meeting and the sixteenth winter meeting of the Ecclesiastical History Society. (pp. 71-86). Oxford, UK: Blackwell

Feher, G. (1984). Bulgar Türkleri tarihi. Ankara:Türk Tarih Kurumu Yayınları.

Foederati. (2018, 31 Ağustos). In Priceton. Retrieved from https://www.princeton.edu/ achaney/ tmve/wiki100k/docs/Foederati.html

Golden, P. B. (2006). Türk halkları tarihine giriş (O. Karatay, Çev.) Çorum: Karam.

Gökdağ, B. ve Karatay, O. (Ed.). (2013). Balkanlar el kitabı (C. 1): Tarih. Ankara: Akçağ Yayınları. 
Güzel, H. C., Çiçek, K. ve Koca, S. (Ed.). (2002). Türkler (C. 6). Ankara: Yeni Türkiye Yayınları.

Hodgkin, T. (2001). The barbarian invasions of the Roman Empire (Vols. 1-5). London, UK: The Folio Society.

Illyria. (2018, 31 Ağustos). In Encyclopedia Britannica. Retrieved from https://www.britannica.com/ place/Illyria

Kafesoğlu, İ. (1985). Bulgarların kökeni. Ankara: Türk Kültürünü Araştırma Enstitüsü.

Karatay, O. (2004). Doğu Avrupa Türk tarihinin ana hatları -Altın Orda öncesi dönem. Karadeniz Araştırmaları 3, 1-70.

Karatay, O. (2013a). Oğurlar. O. Karatay \& S. Acar (Ed.), Doğu Avrupa Türk tarihi içinde (s. 241-250). İstanbul: Kitabevi.

Karatay, O. (2013b) Tuna Bulgarları. O. Karatay \& S. Acar (Ed.), Doğu Avrupa Türk tarihi içinde (s. 273294). İstanbul: Kitabevi.

Karatay, O. ve Acar, S. (Ed.). (2013). Doğu Avrupa Türk tarihi. İstanbul: Kitabevi.

Kayapınar, A. (2013) Bulgarların Balkanlara göçü ve Tuna Bulgar Devleti. B. Gökdağ \& O. Karatay (Ed.). Balkanlar el kitabı. 1. cilt: Tarih içinde (s. 105-128). Ankara: Akçağ Yayınları.

Levtchenko, M. V. (2007). Bizans tarihi (M. Selen, Çev.) İstanbul: Doruk.

Limes. (2018, 31 Ağustos). In Encyclopedia Britannica. Retrieved from https://www.britannica.com/ technology/limes

Mangaltepe, İ. (2013). Avarlar (558-822). O. Karatay \& S. Acar (Ed.), Doğu Avrupa Türk tarihi içinde (s. 203-340). İstanbul: Kitabevi.

Mango, C. (Ed.). (2002). The Oxford history of Byzantium. Oxford, UK: University Press.

Mango, C. (2005). Byzantium the empire of the new Rome. London, UK: Phoenix.

Meanchen-Helfen, O. J. (1973). The world of the Huns. Studies in their history and culture. Berkeley, CA: University of California Press.

Moesia. (2018, 31 Ağustos). In Encyclopedia Britannica. Retrieved from https://www.britannica.com/ place/Moesia

Obolensky, D. (1997). The Byzantine commonwealth: Eastern Europe, 500-1453. New York, NY: St. Vladimir's Seminay Press.

Opsikion. (2018, 31 Ağustos). In WikiVisually. Retrieved from https://wikivisually.com/wiki/Opsikion

Pannonia. (2018, 31 Ağustos). In Encyclopedia Britannica. Retrieved from https://www.britannica.com/ place/Pannonia

Rasonyi, L. (1984). Tuna köprüleri (H. Akın, Çev.) Ankara: Türk Kültürünü Araştırma Enstitüsü.

Rona-Tas, A. (1996). An 'Avar' Word: terem. In A. Berta, B. Brendemoen \& C. Schönig (Eds.), Symbolae Turcologicae: Studies in honour of Lars Johanson on his sixtieth birthday. (pp. 181-188). Stockholm, SE: Svenska Forskningsinstitutet Istanbul.

Runciman, S. (1930). A history of the first Bulgarian Empire. London, UK: G. Bell \& Sons Ltd. 
Setton, K. M. (1950). The Bulgars in the Balkans and the occupation of Corinth in the seventh century. Speculum 25(4), 502-543.

Sinor, D. (2000). Hun dönemi (M. Tuncay, Çev.). D. Sinor (Ed.), Erken lç Asya tarihi içinde (s. 145-282). İstanbul: Iletişim.

Sinor, D. (Ed.). (2000). Erken lç Asya tarihi. İstanbul: Illetişim.

Stepanov, T. (2010). The Bulgars and the steppe empire in the early Middle Ages: The problem of others. Boston, MA: Brill.

Szadeczky-Kardos, S. (2000). Avarlar (R. Sezer, Çev.). D. Sinor (Ed.), Erken lç Asya tarihi içinde (s. 283310). İstanbul: Illetişim.

Thompson, E. A. (2008). Hunlar (S. Dinçel, Çev.). Ankara: Phoenix.

Thrace. (2018, 31 Ağustos). In WikiVisually. Retrieved from https://wikivisually.com/wiki/ Thrace_\%28theme\%29

Treadgold, W. (2002). The struggle for survival (641-780). In C. Mango (Ed.), The Oxford history of Byzantium (pp. 129-152). Oxford, UK: University Press.

Üren, U. (2013). Büyük Bulgar Devleti. O. Karatay \& S. Acar (Eds.), Doğu Avrupa Türk tarihi içinde (251271). İstanbul: Kitabevi.

Vryonis, S. (1967). Byzantium and Europe. London, UK: Thames and Hudson.

Vryonis, S. (1981). The evolution of Slavic society and Slavic invasions in Greece. The first major Slavic attack on Thessaloniki, A.D. 597. Hesperia 50(4), 378-390.

Whittow, M. (1996). The making of Orthodox Byzantium, 600-1025. London, UK: Palgrave Macmillan. 